\title{
Host jumps shaped the diversity of extant rust fungi (Pucciniales)
}

\author{
Alistair R. McTaggart ${ }^{1}$, Roger G. Shivas ${ }^{2}$, Magriet A. van der Nest ${ }^{3}$, Jolanda Roux ${ }^{4}$, Brenda D. Wingfield ${ }^{3}$ and \\ Michael J. Wingfield ${ }^{1}$

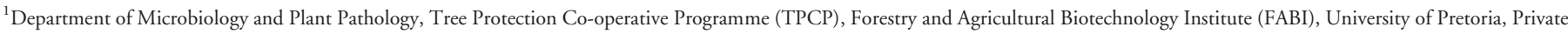 \\ Bag X20, Pretoria 0028, South Africa; ${ }^{2}$ Department of Agriculture and Forestry, Queensland Plant Pathology Herbarium, GPO Box 267, Brisbane, Qld 4001, Australia; ${ }^{3}$ Department of \\ Genetics, Forestry and Agricultural Biotechnology Institute (FABI), University of Pretoria, Private bag X20, Pretoria 0028, South Africa; ${ }^{4}$ Department of Plant Sciences, Tree Protection \\ Co-operative Programme (TPCP), Forestry and Agricultural Biotechnology Institute (FABI), University of Pretoria, Private Bag X20, Pretoria 0028, South Africa
}

Author for correspondence:

Alistair R. McTaggart

Tel: +27124206714

Email: alistair.mctaggart@gmail.com

Received: 8 July 2015

Accepted: 26 August 2015

New Phytologist (2016) 209: 1149-1158

doi: $10.1111 /$ nph.13686

Key words: calibration, host jumps, host-parasite evolution, Mikronegeriaceae, molecular dating, Pucciniales, Uredinales.

\section{Summary}

- The aim of this study was to determine the evolutionary time line for rust fungi and date key speciation events using a molecular clock. Evidence is provided that supports a contemporary view for a recent origin of rust fungi, with a common ancestor on a flowering plant.

- Divergence times for $>20$ genera of rust fungi were studied with Bayesian evolutionary analyses. A relaxed molecular clock was applied to ribosomal and mitochondrial genes, calibrated against estimated divergence times for the hosts of rust fungi, such as Acacia (Fabaceae), angiosperms and the cupressophytes.

- Results showed that rust fungi shared a most recent common ancestor with a mean age between 113 and 115 million yr. This dates rust fungi to the Cretaceous period, which is much younger than previous estimations. Host jumps, whether taxonomically large or between host genera in the same family, most probably shaped the diversity of rust genera. Likewise, species diversified by host shifts (through coevolution) or via subsequent host jumps. This is in contrast to strict coevolution with their hosts.

- Puccinia psidii was recovered in Sphaerophragmiaceae, a family distinct from Raveneliaceae, which were regarded as confamilial in previous studies.

\section{Introduction}

Rust fungi (Pucciniales, Pucciniomycotina) are the most species rich group of obligate, plant pathogenic fungi. They include many important plant pathogens such as Puccinia graminis (wheat stem rust), Hemileia vastatrix (coffee rust) and Cronartium ribicola (white pine blister rust). The divergence of rust fungi was thought to mirror the evolution of their host plants (Savile, 1976, 1979; Anikster \& Wahl, 1979). Thus, ancestral species of rust have been considered pathogens of ferns (monilophytes) and gymnosperms, with succession to angiosperms (Cunningham, 1931; Leppik, 1953, 1965; Savile, 1976). Leppik (1965) hypothesized that the first ancestor of rust fungi may have evolved 200-300 million yr ago (Ma) on mosses (bryophytes) and ancient ferns (leptosporangiates, which excludes the Polypodiales), and have extant relatives in the genera Eocronartium and Jola (Platygloeales, Pucciniomycotina). This correlates with the evolutionary divergence times for ferns, gymnosperms and angiosperms at c. 394, 312 and $194 \mathrm{Ma}$ (Magallón etal., 2013).

Hart (1988) challenged the notion that ancestral hosts harbored ancestral parasites. This was based on a phylogenetic analysis with morphological characters from 30 genera of rust fungi. Hart (1988) suggested that ancestral rusts were autoecious (completed their life cycle on one host), short-cycled and evolved on angiosperms in tropical climates. He further proposed that the rusts on ferns and pines (Pinales) were derived, and groups now classified as the suborders Uredinineae sensu Aime (2006) and Melampsorineae sensu Aime (2006) diverged at the same time. Sjamsuridzal etal. (1999) determined that fern rusts were not ancestral in the Pucciniales with a molecular phylogenetic study that supported the conclusions of Hart (1988).

An evolutionary origin of rust fungi on angiosperms was supported by Aime (2006), who showed that some extant species, including $H$. vastatrix (on Rubiaceae), Blastospora smilacis (on Smilacaceae) and Maravalia cryptostegiae (on Apocynaceae), belonged to an ancestral family, Mikronegeriaceae (Pucciniales). This family is typified by Mikronegeria, which is heteroecious on gymnosperms and Nothofagus (Nothofagaceae, Fagales), or, in the case of M. fuchsiae, on a gymnosperm and Fuchsia (Onagraceae) (Crane \& Peterson, 2007).

The most ancestral member of the Pucciniales recovered by Aime (2006) was Caeoma torreyae on a gymnosperm, Torreya californica (Taxaceae, Pinales). Peterson (1974) first proposed that $C$. torreyae was an ancestral rust that existed in the Mesozoic or early Cenozoic, between 66 and $250 \mathrm{Ma}$. C. torreyae occurs on Torreya, which diverged c. $138 \mathrm{Ma}$ (Magallón et al., 2013). The divergence time of the cupressophytes, which include Torreya and the aecial hosts of Mikronegeria, namely Araucaria and Austrocedrus, was estimated at $257 \mathrm{Ma}$ (Magallón et al., 2013). 
Estimates for the age of rust fungi have varied considerably. Wingfield etal. (2004) estimated that rust fungi evolved as recently as $150 \mathrm{Ma}$ on primitive angiosperms. This estimation was based on a set rate of nucleotide changes in the small subunit (SSU) region of ribosomal DNA. However, Aime (2006) estimated that rusts were an older group, c. $250 \mathrm{Ma}$, as this was similar to the ages of Araucariaceae and Taxaceae, and predated the break-up of the supercontinent Pangaea c. 138-160 Ma (Mao et al., 2012).

A difficulty for molecular dating of fungi is the lack of fossil evidence used to calibrate divergence times for extant lineages (Berbee \& Taylor, 2010). This is the case for rust fungi (Pucciniales), which are obligate pathogens and are mostly represented by fossils up to $70 \mathrm{Ma}$ (Tiffney \& Barghoorn, 1974; Savile, 1976). The underlying assumption of the present study is that the estimated times of host divergence, based on fossil evidence, provide a calibration point for the divergence times of parasites that share a coevolutionary relationship.

The aim of this study was to determine the evolutionary time line for the rust fungi and to date key speciation events with a molecular clock. The divergence dates of extant groups of rust fungi have never been studied with a molecular clock calibrated to definitive points in time. A Bayesian dating approach with three gene regions from ribosomal DNA and mitochondrial DNA was used to estimate the ages of monophyletic groups of rust fungi. The divergence times calculated in this study shed light on the common mechanisms for speciation in rust fungi.

\section{Materials and Methods}

\section{Taxon selection}

Representative species were selected from genera for which there are sequence data on GenBank for the large subunit (LSU) and SSU regions of ribosomal DNA (rDNA), and cytochrome c oxidase subunit 3 (CO3) of mitochondrial DNA (Table 1). Sequence data for tropical rust fungi on angiosperms obtained in a study on Australian rust fungi (Shivas et al., 2014) were included and uploaded to GenBank (Table 1). These genera included Achrotelium, Ceratocoma, Coleosporium, Cystopsora, Hemileia, Phragmidium, Sphaerophragmium, Thekopsora and Uromyces.

\section{Phylogenetic analyses}

The SSU, LSU and CO3 sequences were aligned with the MAFFT algorithm (Katoh etal., 2009) in SATe-II (Liu et al., 2012). Eocronartium and Helicobasidium were selected as outgroup taxa based on the phylogenetic study by Aime (2006). The three alignments were concatenated and run as partitioned datasets with maximum likelihood and Bayesian inference as phylogenetic criteria. GTRGAMMA was specified as the model of evolution in both criteria. Maximum likelihood was implemented as a search criterion in RAxML (Stamatakis, 2014). The RAxML analyses were run with a rapid Bootstrap analysis (command $-\mathrm{f}$ a) using a random starting tree and 1000 maximum likelihood bootstrap replicates. A Markov chain Monte
Carlo search in a Bayesian analysis was conducted with MrBayes (Ronquist \& Huelsenbeck, 2003). Four runs, each consisting of four chains, were implemented for 2.6 million generations until the standard deviation of split frequencies was $<0.008$. The cold chain was heated at a temperature of 0.25 . Substitution model parameters were sampled every 1000 generations and trees were saved every 1000 generations. Convergence of the Bayesian analysis was confirmed using AWTY (Nylander et al., 2008) (available at: ceb.csit.fsu.edu/awty/). A burn-in of $25 \%$ was used and 8000 trees were summarized for the final topology. The maximum likelihood and Bayesian analyses were run three times to test accuracy. Alignments and trees were uploaded to TreeBASE (http://purl.org/phylo/treebase/phylows/study/TB2:S17850).

\section{Molecular dating analyses}

Bayesian evolutionary analysis by sampling trees was implemented in BEAST 2 (Bouckaert et al., 2014), which allowed estimation of the divergence times of monophyletic groups of rust fungi from their most recent common ancestors. The LSU, SSU and CO3 regions were run as separate partitions with GTR $+\mathrm{I}+\Gamma$ and HKY as substitution site models, a gamma category count of four, and estimated parameters. A lognormal relaxed clock, which proposes that nucleotide changes occur at variable rates within lineages or in particular genes, was used as the clock model, and the Yule model was used as a tree prior for a constant birth-death, which is appropriate for trees with different species (Drummond \& Bouckaert, 2015). Outgroups used in the phylogenetic analyses were excluded from the BEAST analyses as recommended by Drummond \& Bouckaert (2015). A congruent topology obtained from maximum likelihood and Bayesian inference was fixed as a topology for the BEAST analyses. Two separate BEAST analyses that differed at the calibration of Pucciniales were run for 30 million generations, with trees logged every 1000 generations. TRACER v.1.6.0 (Rambaut etal., 2014) was used to determine the behavior of the chains and to test the confidence of estimated parameters with the effective sample sizes (ESS). The mean node ages and 95\% highest posterior density (HPD) values were summarized and annotated on the final topologies with TreeAnnotator v2.2.0 (Drummond et al., 2012).

\section{Calibration of nodes}

Nodes were calibrated in BEAUTi 2 (Bouckaert et al., 2014) based on mean divergence times for the hosts of rust fungi. A normal distribution was selected for the data as recommended by Ho (2007) and Drummond \& Bouckaert (2015). The age of the rust node was calibrated so the mean age of host divergence was the maximum age in the $97.5 \%$ quantile of the distribution of the prior (priors are defined in Table 2 and calibrated nodes are shown in Fig. 1). This is weighted to host-tracking rather than cospeciation, and assumes a lag time between the evolution of the parasite and its host (Roy, 2001). Nodes within Endoraecium were calibrated based on evidence that these rusts coevolved with 
Table 1 Species of rust, specimen number, host and GenBank numbers of taxa included in the analyses

GenBank number

Taxon

Achrotelium ichnocarpi Syd.

Caeoma torreyae Bonar

Ceratocoma jacksoniae

(Henn. ex McAlpine) Buriticá \& J.F. Hennen

Chrysomyxa cassandrae (Gobi) Tranzschel

Chrysomyxa ledi (Alb. \& Schwein.) de Bary

Chrysomyxa ledicola Lagerh.

Chrysomyxa nagodhii P.E. Crane

Chrysomyxa pyrolae Rostr.

Coleosporium tussilaginis (Pers.) Lév.

Cystopsora notelaeae Syd.

Dasyspora amazonica Beenken

Dasyspora echinata Beenken \& Berndt

Dasyspora gregaria (Kunze) Henn.

Dasyspora guianensis Beenken

Dasyspora mesoamericana Beenken

Dasyspora nitidae Beenken

Dasyspora segregaria Beenken

Dasyspora winteri (Pazschke) Beenken

Endoraecium acaciae Hodges \& D.E. Gardner

Endoraecium auriculiforme McTaggart \& R.G. Shivas

Endoraecium carnegiei McTaggart \& R.G. Shivas

Endoraecium disparrimum McTaggart \& R.G. Shivas

Endoraecium falciforme McTaggart \& R.G. Shivas

Endoraecium irroratum McTaggart \& R.G. Shivas

Endoraecium koae (Arthur) M. Scholler \& Aime

Endoraecium maslinii McTaggart \& R.G. Shivas

Endoraecium parvum Berndt

Endoraecium peggii McTaggart \& R.G. Shivas

Endoraecium phyllodiorum (Berk. \& Broome) Berndt

Endoraecium podalyriifolium McTaggart \& R.G. Shivas

Endoraecium tierneyi

(J. Walker \& R.G. Shivas) M. Scholler \& Aime

Endoraecium tropicum McTaggart \& R.G. Shivas

Endoraecium violae-faustiae Berndt

Eocronartium muscicola (Pers.) Fitzp.

Gerwasia rubi Racib.

Hamaspora acutissima P. Syd. \& Syd.

Helicobasidium purpureum (Tul.) Pat.

Hemileia vastatrix Berk. \& Broome

Hemileia sp.

Maravalia cryptostegiae (Vestergr.) Y. Ono

Masseeëlla capparis (Hobson bis ex Cooke) Dietel

Melampsora abietis-canadensis C.A. Ludw.

Melampsora aecidioides (DC.) J. Schröt.

Melampsora medusae f.sp. tremuloides Shain

Melampsora pinitorqua Rostr.

Phakopsora annonae-sylvaticae Beenken

Phakopsora cherimoliae (Lagerh.) Cummins

Phakopsora crucis-filii

(Dianese, R.B. Medeiros \& L.T.P. Santos) Beenken

Phakopsora myrtacearum

McTaggart, Maier, Jol. Roux, M.J. Wingf.

Phakopsora pistila (Buriticá \& J.F. Hennen) Beenken

Phakopsora rolliniae (W.T. Dale) Beenken

Phragmidium barnardii Plowr. \& G. Winter

Phragmidium potentillae (Pers.) P. Karst.

Puccinia lagenophorae Cooke
Specimen

BRIP 55634

BRIP 57762

TChnocarpus frutescens
Torreya californica

Davesia sp.

NA

DAOM 149959 Rhododendron palustre

NA

NA

NA

BRIP 56944

BRIP 58325

BPI 0116382

PUR N6196

ZT Myc 3397

ZT Myc 3413

PUR 42390

ZT Myc 3409

PMA MP4941

S F30078

BPI 871098

BRIP 56548

BRIP 57924

BRIP 55626

BRIP 57583

BRIP 57286

BPI 871071

BRIP 57872

BRIP 57524

BRIP 55602

BRIP 57516

BRIP 57576

BRIP 27071

BRIP 56557

BRIP 55601

NA

BRIP 58369

BRIP 55606

TUB 011542

BRIP 61233

BRIP 57470

BRIP 56898

BRIP 56844

NA

NA

NA

NA

PUR 87311

NA

ZT Myc 48990

\section{PREM 61155}

ZT Myc 48992

ZT Myc 49000

BRIP 56945

BRIP 60089

BRIP 57563

\begin{tabular}{lll}
\hline LSU & SSU & CO3 \\
\hline KT199393 & KT199381 & KT199404 \\
AF522183 & AY123284 $^{2}$ & NA \\
KT199394 & KT199382 & KT199405
\end{tabular}

FJ66645 3

FJ666468 ${ }^{3}$ NA $\quad$ FJ666445 ${ }^{3}$

$\begin{array}{lll}\text { FJ } 666446^{3} & \text { NA } & \text { FJ666423 }\end{array}$

$\begin{array}{lll}\text { FJ666461 } & \text { NA NJ666438 } \\ \end{array}$

FJ666466 ${ }^{3}$ NA FJ666443 ${ }^{3}$

KT199395 KT199383 KT199406

$\begin{array}{lll}\text { KT199396 KT199384 KT199407 } & \text { KT }\end{array}$

$\begin{array}{lll}J F 263460^{4} & J F 263496^{4} & J F 263512^{4}\end{array}$

$\begin{array}{lll}\text { JF263462 } & { }^{4} \quad J F 263497^{4} & J F 263513^{4}\end{array}$

JF263477 ${ }^{4} \quad J F 263502^{4} \quad J F 263518^{4}$

$\begin{array}{lll}J F 263479^{4} & J F 263503^{4} & J F 263519^{4}\end{array}$

JF263480 $\quad J F 263504^{4} \quad J F 263520^{4}$

JF263484 4 JF263505 ${ }^{4} \quad J F 263521^{4}$

$\begin{array}{lll}\text { JF263488 } & \text { JF263507 } & \text { JF263523 } \\ & \end{array}$

$\begin{array}{lll}J F 263492^{4} & J F 263508^{4} & J F 263524^{4}\end{array}$

DQ323916 $^{5}$ DQ323917 $^{5} \quad \mathrm{NA}$

KJ862298 ${ }^{6} \quad \mathrm{NA} \quad \mathrm{KJ}^{\circ} 862432^{6}$

$\mathrm{KJ} 862301^{6} \quad \mathrm{NA} \quad \mathrm{KJ} 862435^{6}$

KJ862304 ${ }^{6} \quad \mathrm{KJ} 862403^{6} \quad \mathrm{KJ}^{6} 82437^{6}$

KJ862306 ${ }^{6} \quad K^{\prime} 862405^{6} \quad K^{6} 862439^{6}$

KJ862312 ${ }^{6} \quad K^{\prime} 8862407^{6} \quad K^{2} 862442^{6}$

DQ323918 ${ }^{5}$ DQ323919 $\quad$ NA

KJ862314 ${ }^{6} \quad K^{\prime} 862408^{6} \quad K^{6} 862444^{6}$

$\begin{array}{lll}\text { KJ862316 } & \text { KJ862409 } & \text { KJ862445 }\end{array}$

KJ862308 ${ }^{6} \quad \mathrm{NA} \quad \mathrm{KJ} 862440^{6}$

KJ862324 ${ }^{6} \quad K^{\prime} J 862411^{6} \quad K J 862447^{6}$

KJ862334 ${ }^{6} \quad K^{\prime} 862414^{6} \quad K^{\prime} 862449^{6}$

KJ862335 ${ }^{6} \quad K^{\prime} 862415^{6} \quad K J 862450^{6}$

$\begin{array}{lll}\text { KJ862337 } & \text { KJ862417 } & \text { KJ862452 } \\ & \end{array}$

KJ862338 ${ }^{6} \quad K^{\prime} 862418^{6} \quad K^{\prime} 862453^{6}$

AF014825 ${ }^{1} \quad \mathrm{DQ}^{241438^{7}}$ NA

KT199397 NA KT199408

KT199398 KT199385 KT199409

AY254180 ${ }^{8} \quad \mathrm{D}^{2} 5648^{9} \quad$ NA

KT199399 DQ354565 ${ }^{10}$ KT199410

$\begin{array}{lll}\text { KT199400 KT199386 } & \text { KT199411 }\end{array}$

$\begin{array}{lll}\text { KT199401 } & \text { KT199387 } & \text { KT199412 }\end{array}$

JX136798 ${ }^{11}$ NA KT199413

$\begin{array}{lll}\mathrm{FJ} 666512^{3} & \mathrm{NA} & \mathrm{FJ} 666542^{3}\end{array}$

$\begin{array}{lll}\mathrm{FJ} 666520^{3} & \mathrm{NA} & \mathrm{FJ} 666550^{3}\end{array}$

$\begin{array}{lll}\mathrm{FJ} 666517^{3} & \mathrm{NA} & \mathrm{FJ}^{3} 666547^{3}\end{array}$

${\text { FJ } 666523^{3}}^{3} \quad$ NA FJ666553 ${ }^{3}$

KF528008 ${ }^{12} \quad$ KF528038 $^{12} \quad$ KF52 $^{2} 8046^{12}$

$K^{K F 528011^{12}} K^{K F 528040^{12}}$ KF528048 $^{12}$

KF528016 ${ }^{12}$ KF528041 $^{12} \quad$ KF528049 ${ }^{12}$

$\begin{array}{lll}K^{2} 729473^{13} & N A & \text { KT199414 }\end{array}$

KF528026 ${ }^{12} \quad K^{12} 528043^{12} \quad K^{12} 528051^{12}$

KF528034 ${ }^{12}$ KF528045 $^{12} \quad$ KF528054 $^{12}$

KT199402 NA KT199415

KT199403 NA KT199416

$\begin{array}{lll}\mathrm{KF} 690696^{15} & \mathrm{KT} 199388 & \mathrm{KT} 199417\end{array}$ 


\begin{tabular}{|c|c|c|c|c|c|}
\hline \multirow[b]{2}{*}{ Taxon } & \multirow[b]{2}{*}{ Specimen } & \multirow[b]{2}{*}{ Host of specimen } & \multicolumn{3}{|c|}{ GenBank number } \\
\hline & & & LSU & SSU & $\mathrm{CO} 3$ \\
\hline Puccinia myrsiphylli (Thüm.) G. Winter & BRIP 57782 & Asparagus asparagoides & KM249854 & NA & KT199418 \\
\hline Puccinia psidii G. Winter & BRIP 57793 & Rhodamnia angustifolia & KF318449 14 & KF318457 $7^{14}$ & KT199419 \\
\hline Puccinia stylidii McAlpine & BRIP 60107 & Stylidium armeria & KJ622215 & KT199389 & KT199420 \\
\hline Puccinia ursiniae R.G. Shivas & BRIP 57993 & Ursinia anthemoides & KF690705 & KT199390 & KT199421 \\
\hline Sphaerophragmium acaciae (Cooke) Magnus & BRIP 56910 & Albizzia sp. & KJ8623506 & KJ8624296 & KJ862462 \\
\hline $\begin{array}{l}\text { Sphenorchidium polyalthiae } \\
\text { (Syd. \& P. Syd.) Beenken \& A.R. Wood }\end{array}$ & ZT HeRB 251 & Polyalthia longifolia & $J F 263493^{4}$ & $J F 263509^{4}$ & $J F 263525^{4}$ \\
\hline Thekopsora minima (Arthur) P. Syd. \& Syd & BRIP 57654 & Vaccinium corymbosum & KC763340 ${ }^{16}$ & KT199391 & KT199422 \\
\hline Uromyces lomandracearum J. Walker \& van der Merwe & BRIP 59022 & Lomandra sp. & KM249862 & KT199392 & KT199423 \\
\hline Uromycladium acaciae (Cooke) P. Syd. \& Syd. & BRIP 60092 & Acacia terminalis & KR994853 ${ }^{17}$ & KR994932 17 & KR995046 ${ }^{17}$ \\
\hline Uromycladium sp. & BRIP 59239 & Acacia mearnsii & KR994852 ${ }^{17}$ & KR994931 & KR995045 ${ }^{17}$ \\
\hline $\begin{array}{l}\text { Uromycladium falcatarium } \\
\text { Doungsa-ard, McTaggart \& R.G. Shivas }\end{array}$ & BRIP 57447 & Falcataria moluccana & $\mathrm{KJ} 632973^{18}$ & $\mathrm{KJ} 633013^{18}$ & $\mathrm{KJ} 639059^{18}$ \\
\hline Uromycladium fusisporum (Cooke \& Massee) Savile & BRIP 57526 & Acacia salicina & KJ632991 ${ }^{18}$ & $\mathrm{KJ} 633031^{18}$ & $\mathrm{KJ} 639075^{18}$ \\
\hline Uromycladium naracoortensis Berndt & MEL 2359562 & Acacia iteaphylla & KR994880 17 & KR994958 ${ }^{17}$ & KR995071 17 \\
\hline Uromycladium notabile (F. Ludw.) McAlpine & BRIP 59234 & Acacia dealbata & KJ632992 $2^{18}$ & KJ633030 ${ }^{18}$ & $\mathrm{KJ} 639076^{18}$ \\
\hline Uromycladium simplex McAlpine & BRIP 59214 & Acacia pycnantha & KJ632990 ${ }^{18}$ & KJ633029 & $\mathrm{KJ} 639078^{18}$ \\
\hline Uromycladium tepperianum (Sacc.) McAlpine & BRIP 56928 & Acacia leiocalyx & $\mathrm{KJ} 632981^{18}$ & $\mathrm{KJ} 633017^{18}$ & $\mathrm{KJ} 639073^{18}$ \\
\hline Uromycladium tepperianum & BRIP 57860 & Acacia saligna & KJ632988 & $\mathrm{KJ} 633027^{18}$ & KJ639069 ${ }^{18}$ \\
\hline
\end{tabular}

NA, sequences were not available. [Correction added after online publication 13 October 2015: in the 'Host of specimen' column, Pinus alba and Pinus tremuloides have been corrected to Populus alba and Populus tremuloides, respectively.] GenBank numbers obtained for this study are shown in bold font. ${ }^{1}$ T. D. Bruns \& T. M. Szaro (unpublished); ${ }^{2}$ Wingfield et al. (2004); ${ }^{3}$ Vialle et al. (2009); ${ }^{4}$ Beenken et al. (2012); ${ }^{5}$ Scholler \& Aime (2006); ${ }^{6}$ McTaggart et al. (2015); ${ }^{7}$ Henk \& Vilgalys (2007); ${ }^{8}$ Lutz et al. (2004); ${ }^{9}$ S. Kuninaga (unpublished); ${ }^{10}$ Aime (2006); ${ }^{11}$ Liberato et al. (2014); ${ }^{12}$ Beenken (2014); ${ }^{13}$ Maier et al. (2015); ${ }^{14}$ Pegg et al. (2014); ${ }^{15}$ McTaggart etal. (2014); ${ }^{16}$ McTaggart et al. (2013); ${ }^{17}$ C. Doungsa-ard (unpublished); ${ }^{18}$ Doungsa-ard et al. (2015). LSU, large subunit region of ribosomal DNA (rDNA); SSU, small subunit region of rDNA; CO3, cytochrome c oxidase subunit 3 of mitochondrial DNA.

their host species in the genus Acacia (McTaggart et al., 2015). The divergence dates for species of Acacia were determined by Miller et al. (2013), and five calibration points were provided for Endoraecium and Uromycladium (21.2 Ma maximum age in 97.5\% quantile), and species of Endoraecium monophyletic on subclade Botrycephaleae (7.0 Ma maximum age in $97.5 \%$ quantile), Juliflorae (11.0 Ma maximum age in $97.5 \%$ quantile) and Plurinerves (10.3 Ma maximum age in $97.5 \%$ quantile) (Table 2). The Pucciniales were calibrated to the maximum mean divergence age of angiosperms (193.76 Ma maximum age in $97.5 \%$ quantile) determined by Magallón et al. (2013). This calibration is based on a most recent common ancestor of rust fungi evolving on angiosperms (Hart, 1988). A second analysis was made with the Pucciniales calibrated to the divergence age of the cupressophytes, which are hosts of the most ancestral species of rust, C. torreyae and Mikronegeria spp. (Aime, 2006). The cupressophytes were calibrated between 136 and $256 \mathrm{Ma}$, which included the divergence of Torreya as the lowest age, and the mean age of the cupressophytes determined by Magallón et al. (2013) as the upper age. The.$x m l$ files are available from the corresponding author.

\section{Results}

\section{Phylogenetic analyses}

Bayesian inference and maximum likelihood recovered congruent topologies (Fig. 1). The topologies reflected the familial classification recognized by Aime (2006), who recovered eight phylogenetically supported families. There were three exceptions: the Pucciniastraceae and Sphaerophragmiaceae were recognized as distinct families, and the position of Uromycladium was unresolved.

Thekopsora minima was recovered sister to the Melampsoraceae, and its inclusion in the Coleosporiaceae sensu Aime (2006) would make this family polyphyletic. It was treated in the Pucciniastraceae sensu Cummins \& Hiratsuka (2003). Puccinia psidii was recovered in Sphaerophragmiaceae sensu Cummins \& Hiratsuka (1983), a family distinct from the Raveneliaceae as considered by more recent authors (Cummins \& Hiratsuka, 2003; Wingfield et al., 2004). Uromycladium was recovered sister to genera in Phakopsoraceae and Raveneliaceae. Cummins \& Hiratsuka (2003) considered Uromycladium a member of the Pileolariaceae, and a monophyletic Pileolariaceae sensu stricto containing Pileolaria and Uromycladium was proposed by Aime (2006). Doungsa-ard etal. (2015) determined that Uromycladium was sister to Pileolariaceae, and the results of the present study indicated that it had an unresolved familial position. Cystopsora notelaeae and Achrotelium ichnocarpi were recovered in an ancestral family of rust fungi, Mikronegeriaceae. This is the first molecular evidence to determine the systematic position of these genera, which were placed in the Pucciniaceae and Chaconiaceae by Cummins \& Hiratsuka (2003). Hamaspora and Gerwasia were recovered sister to Phragmidium in Phragmidiaceae, which all occur on members of the Rosaceae. Ceratocoma, which previously had an uncertain familial position, was well resolved within Pucciniaceae. 
Table 2 Calibration ages, mean ages of most recent common ancestor (MRCA) and 95\% highest posterior density (HPD) ranges for selected clades and taxa

\begin{tabular}{|c|c|c|c|c|c|}
\hline \multirow[b]{2}{*}{ Clade/taxon } & \multirow[b]{2}{*}{ Calibration (Ma) } & \multicolumn{2}{|c|}{$\begin{array}{l}\text { Calibrated to divergence of } \\
\text { angiosperms }\end{array}$} & \multicolumn{2}{|c|}{$\begin{array}{l}\text { Calibrated to divergence of } \\
\text { cupressophytes }\end{array}$} \\
\hline & & $\begin{array}{l}\text { Mean age of } \\
\text { MRCA (Ma) }\end{array}$ & $95 \% \mathrm{HPD}(\mathrm{Ma})$ & $\begin{array}{l}\text { Mean age of } \\
\text { MRCA (Ma) }\end{array}$ & $95 \%$ HPD (Ma) \\
\hline $\begin{array}{l}\text { Pucciniales calibrated } \\
\text { to mean age of } \\
\text { angiosperms }\end{array}$ & $\begin{array}{l}2.5 \% \text { quantile }=107 \\
5 \% \text { quantile }=114 \\
\text { Median }=150 \\
95 \% \text { quantile }=186 \\
97.5 \% \text { quantile }=193\end{array}$ & 115.01 & $78.54-150.01$ & NA & NA \\
\hline $\begin{array}{l}\text { Pucciniales calibrated } \\
\text { to divergence of } \\
\text { cupressophytes }\end{array}$ & $\begin{array}{l}2.5 \% \text { quantile }=136 \\
5 \% \text { quantile }=146 \\
\text { Median }=196 \\
95 \% \text { quantile }=246 \\
97.5 \% \text { quantile }=256\end{array}$ & NA & NA & 112.92 & 69.55-160.95 \\
\hline Uromycladium & $\begin{array}{l}2.5 \% \text { quantile }=10.8 \\
5 \% \text { quantile }=11.6 \\
\text { Median }=16.0 \\
95 \% \text { quantile }=20.4 \\
97.5 \% \text { quantile }=21.2\end{array}$ & 16.71 & $12.42-21.18$ & 16.26 & $11.84-20.59$ \\
\hline Endoraecium & $\begin{array}{l}2.5 \% \text { quantile }=10.8 \\
5 \% \text { quantile }=11.6 \\
\text { Median }=16.0 \\
95 \% \text { quantile }=20.4 \\
97.5 \% \text { quantile }=21.2\end{array}$ & 18.52 & $14.54-22.57$ & 17.96 & $13.92-22.03$ \\
\hline $\begin{array}{l}\text { E. auriculiformum } \\
\text { E. disparrimum } \\
\text { E. parvum } \\
\text { E. peggii } \\
\text { E. phyllodiorum } \\
\text { E. tropicae } \\
\text { E. violae-faustiae }\end{array}$ & $\begin{array}{l}2.5 \% \text { quantile }=7.04 \\
5 \% \text { quantile }=7.36 \\
\text { Median }=9.0 \\
95 \% \text { quantile }=10.6 \\
97.5 \% \text { quantile }=11.0\end{array}$ & 8.85 & $7.08-10.68$ & 8.75 & $6.91-10.55$ \\
\hline $\begin{array}{l}\text { E. acaciae } \\
\text { E. koae } \\
\text { E. tierneyi }\end{array}$ & $\begin{array}{l}2.5 \% \text { quantile }=6.34 \\
5 \% \text { quantile }=6.66 \\
\text { Median }=8.3 \\
95 \% \text { quantile }=9.94 \\
97.5 \% \text { quantile }=10.3\end{array}$ & 7.38 & $5.42-9.36$ & 7.37 & $5.40-9.33$ \\
\hline $\begin{array}{l}\text { E. carnegiei } \\
\text { E. falciforme } \\
\text { E. irroratum } \\
\text { E. maslinii } \\
\text { E. podalyriifolium }\end{array}$ & $\begin{array}{l}2.5 \% \text { quantile }=1.0 \\
5 \% \text { quantile }=1.48 \\
\text { Median }=4.0 \\
95 \% \text { quantile }=6.52 \\
97.5 \% \text { quantile }=7.0\end{array}$ & 4.88 & $2.94-6.91$ & 2.70 & $1.60-3.84$ \\
\hline
\end{tabular}

The mean ages and 95\% HPD are provided for two analyses calibrated to the divergence times of angiosperms or cupressophytes.

NA, not applicable. Ma, million yr ago.

Shortened genus $E$. refers to Endoraecium.

\section{Molecular dating analyses}

The BEAST analyses run with $\mathrm{GTR}+\mathrm{I}+\Gamma$ as a nucleotide substitution model had ESS values $<200$ for the posterior and prior parameters, and rates of nucleotide change when viewed in Tracer. These results were not used in the final estimate of ages because they indicate that the rates of change for GTR had low confidence.

The BEAST analyses run with HKY as a nucleotide substitution model had ESS values $>200$ for all parameters when viewed in Tracer. The final topology with mean ages and 95\% HPD range was obtained from the HKY analyses (Fig. 2). The 95\% HPD values for discussed clades are included in Table 2.
The mean node ages were in agreement between the two analyses calibrated to the ages of angiosperms and cupressophytes (Fig. 1). The 95\% HPDs were all slightly younger in the analysis calibrated to cupressophytes than that calibrated to angiosperms. The largest difference between the two calibrations occurred for the most recent common ancestor of the Puccinales. The mean age of this node was $115 \mathrm{Ma}$ with 79-150 95\% HPD calibrated to angiosperms, and $113 \mathrm{Ma}$ with 70-161 95\% HPD calibrated to cupressophytes. These ages were $43 \mathrm{Ma}$ younger than the calibrated mean age for angiosperms and $94 \mathrm{Ma}$ younger than the oldest calibrated age for cupressophytes. 


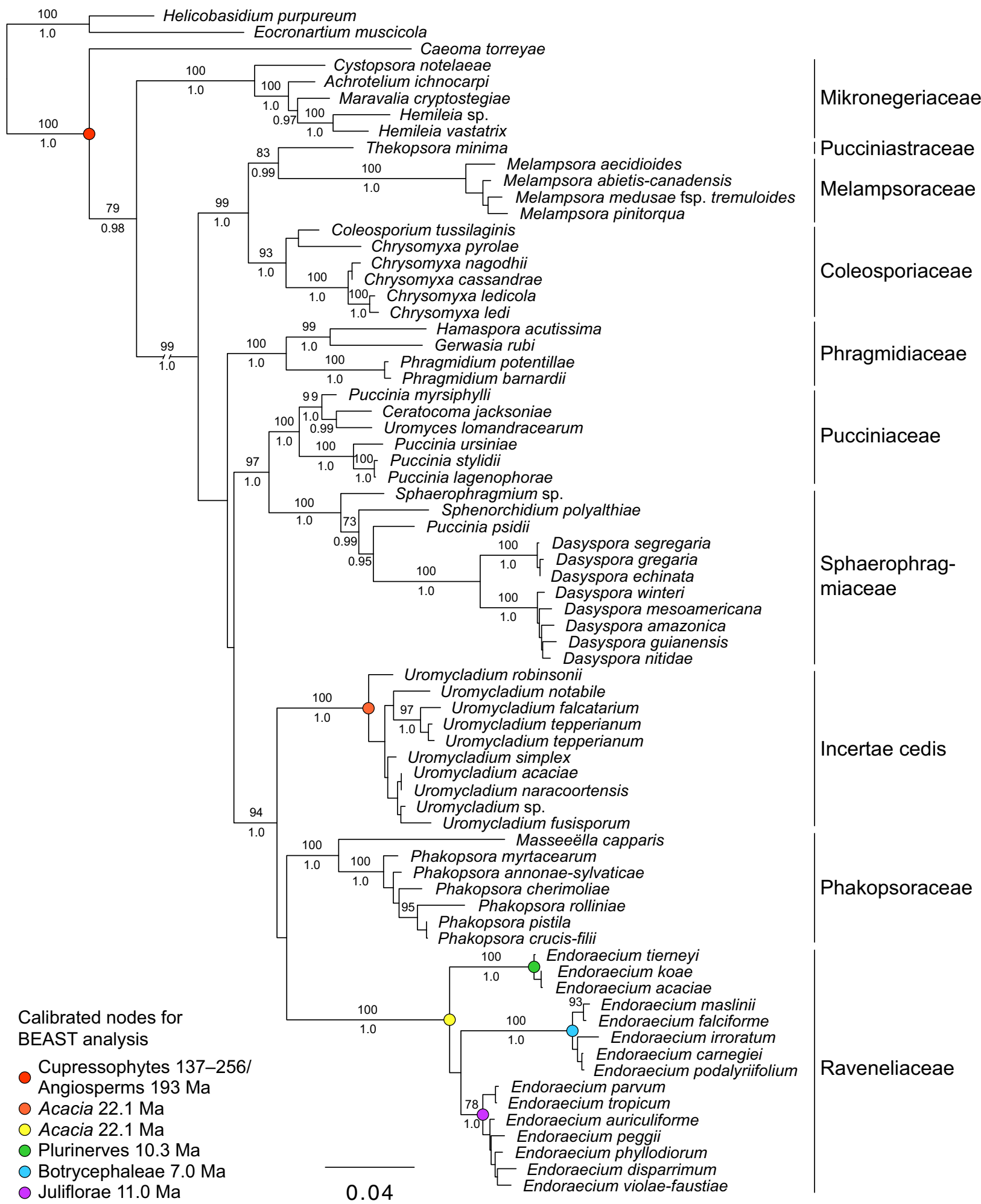

Fig. 1 Phylogram obtained from a maximum likelihood search in RAxML with the large subunit (LSU), small subunit (SSU) and cytochrome c oxidase subunit 3 (CO3) gene regions. Bootstrap values are from 1000 maximum likelihood replicates above nodes and posterior probability values are summarized from 8000 converged trees in a Bayesian search below nodes. This topology was fixed for the BEAST analyses (Fig. 2), and calibrated to the estimated divergence ages of host plants shown at selected nodes. Ma, million yr ago.

\section{Discussion}

When rust fungi first evolved and how they diversified into one of the most important groups of plant pathogens with over 8000 described species and 120 genera on ferns, gymnosperms and angiosperms has never been resolved. This is the first study in which a molecular clock has been used to estimate an evolutionary timescale for rust fungi. Our results indicate that rust fungi shared 
New

Phytologist

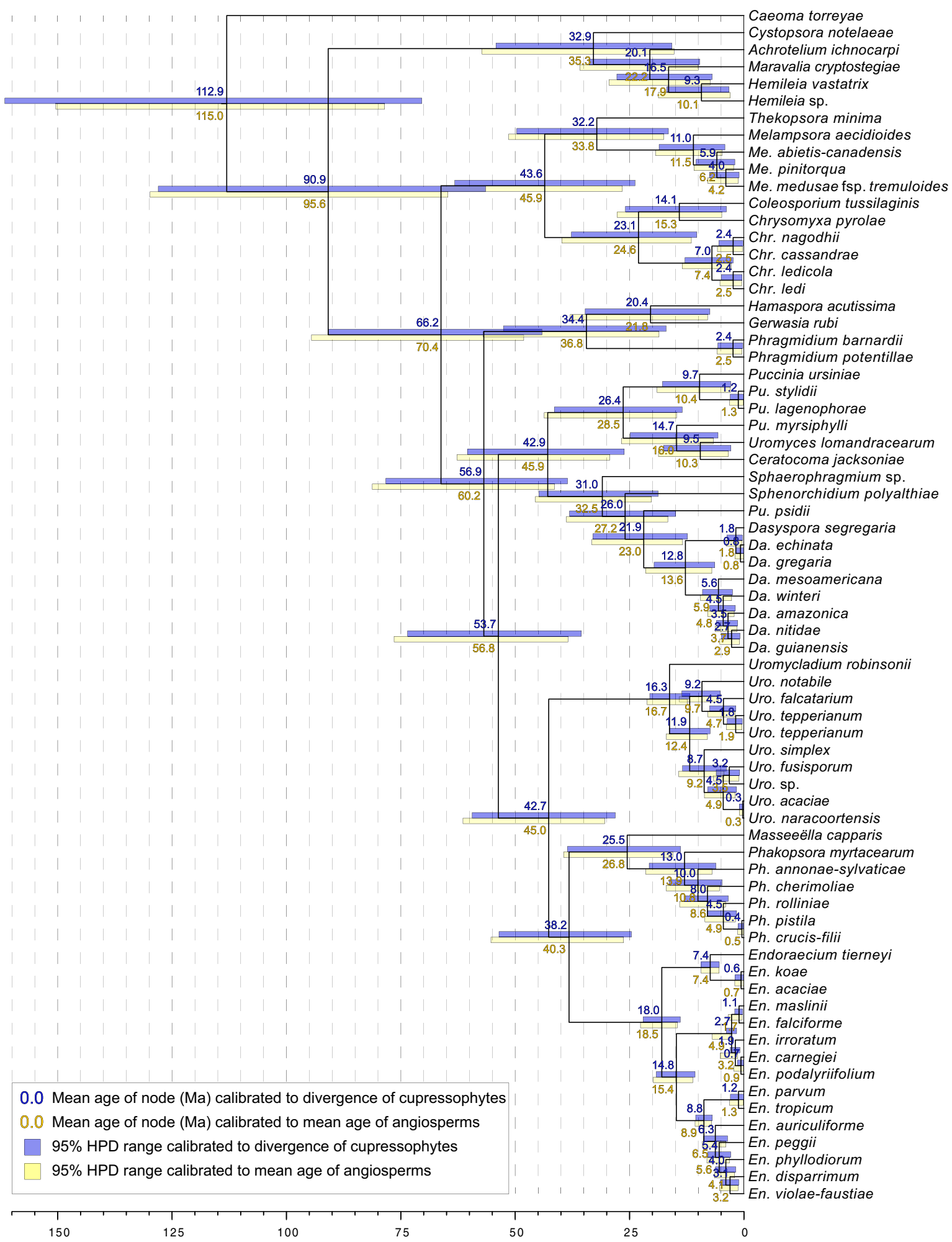

Fig. 2 Phylogram obtained from a BEAST analysis with the Pucciniales calibrated to the divergence age of the cupressophytes. The mean divergence ages calibrated to cupressophytes are above the node (blue), and those calibrated to angiosperms are below the node (yellow). The $95 \%$ highest posterior density (HPD) values calibrated to cupressophytes are above the node (blue), and those calibrated to angiosperms are below the node (yellow). Ma, million yr ago; HPD, highest posterior density.

a most recent common ancestor between 70 and $161 \mathrm{Ma}$, with a mean age of $113-115 \mathrm{Ma}$. This is more recent than most other estimates that lie between 150 and $300 \mathrm{Ma}$ (Leppik, 1965; Savile,
1976; Wingfield et al., 2004; Aime, 2006). This revised age provides evidence that host jumps, rather than coevolution, were the main speciation events that drove the evolution of rust fungi. 
The divergence ages of 70-161 Ma for rust fungi estimated in this study reflect the host ages of ancestral plant species. For example, the gymnosperm Torreya diverged $c .137 \mathrm{Ma}$ (Magallón et al., 2013). Its rust, C. torreyae, was recovered as sister to all other species of rust and is of uncertain familial position. Nothofagus, the telial host of Mikronegeria, diverged 13-113 Ma (Sauquet et al., 2012). The aecial stage of M. fagi and the aecial rusts $A$. balansae and $A$. fragiforme occur on Araucariaceae, which diverged c. $243 \mathrm{Ma}$ (Magallón et al., 2013). These rusts were not included in the present study, but could be ancestral in the Pucciniales, as was first proposed by Aime (2006).

The earliest probable fossil record of a rust was recorded in the Pennsylvanian period (299-323 Ma) by Tiffney \& Barghoorn (1974), which is not consistent with the findings of the current study. This fossil was identified as a species of Teleutosporites (Uromyces) on Lepidodendron, an extinct club moss. Based on the estimated age of rust fungi here and on host taxonomy, this species could be a member of the Platygloeales (Pucciniomycotina), which parasitize species of moss and are sister to the Pucciniales (Aime etal., 2006). Leppik (1965) and Hennen \& Buriticá (1980) considered these fungi as extant ancestors of rust fungi, with unexpanded life cycles.

The revised age for rust fungi found in this study dictates that host jumps, rather than coevolution, were the main speciation events that drove the diversification of rust fungi on angiosperms, gymnosperms and ferns between 70 and $161 \mathrm{Ma}$. The reasoning is that the mean divergence ages of these plant hosts are between 194 and $394 \mathrm{Ma}$, and rust fungi were simply not present at that time. Hart (1988) first hypothesized that host jumps drove the diversification of rust fungi. Genera of rust fungi probably arose from host jump events and then diversified by cospeciation or taxonomically small host shifts. Strict examples of coevolution are seen in species of Endoraecium that infect Acacia (McTaggart et al., 2015) and between genera in the Phragmidiaceae on hosts in Roseaceae, as shown in the present study. Host jumps were seen in genera such as Phakopsora (Maier et al., 2015), Puccinia (van der Merwe etal., 2008; McTaggart etal., 2014) and Uromycladium (Doungsa-ard et al., 2015), and within genera of the Mikronegeriaceae and Sphaerophragmiaceae, as seen in the present study. These findings support the hypothesis that hosts and their parasites are not always the result of long term coevolution (de Vienne et al., 2013).

The results of the present study show that families, genera and species of rust fungi within the two suborders Uredinineae sensu Aime (2006) and Melampsorineae sensu Aime (2006) diverged $c$. 38-46, 22-37 and 0.3-17 Ma, respectively. This was not consistent with a study on the time tree of life (Hedges et al., 2015), which estimated that families, genera and species in the Basidiomycotina diverged c. 111, 98 and $6 \mathrm{Ma}$, respectively (Hedges et al., 2015). Hedges et al. (2015) determined that speciation was clock-like. However, parasites have shorter generations and can make taxonomically large host jumps, which means that less time is required for speciation.

The nature of the compatible reactions that have allowed rust fungi to make large jumps between taxonomically diverse hosts is not known. There are well known pathways of host jumps for rust fungi between pines and ferns (Savile, 1979), Ranunculales and Poales (van der Merwe et al., 2008), Asterales and Cyperaceae (van der Merwe etal., 2008), and Annonaceae and Myrtaceae (Maier etal., 2015). Savile (1971) considered that ecological proximity was another requirement for successful host jumps. A genomic approach that compares genes in closely related species that have lost or gained a life cycle stage (e.g. rusts related by Tranzschel's law) or changed hosts may shed light on the requirements for compatible host-parasite interactions.

Rust fungi are mostly host-specific, and this has been a basic assumption for descriptions of new taxa. Molecular phylogenetic studies have shown that narrow host ranges are common for rust fungi. But there are some notable exceptions, such as in the cases of Puccinia lagenophorae (Scholler etal., 2011) and Uromycladium notabile (C. Doungsa-ard, unpublished) on multiple species, and P. psidii on multiple genera (Pegg et al., 2014). The aecial stages of heteroecious rust fungi considered in this study, namely Coleosporium, Chrysomyxa and Thekopsora, are confined to one or two host genera, with a wider host range observed in the telial stage (Cummins \& Hiratsuka, 2003). Baum \& Savile (1985) highlighted the frequency of host jumps that heteroecious rusts make when they alternate hosts each year. Perhaps there is more plasticity in the host range of rust fungi, particularly in the telial stage, and when rusts are exposed to novel host populations that have not developed resistance. An example is a plastic aecial rust, Cronartium ribicola, which was introduced to North America and spread to native species of Pinus (Kinloch, 2003).

Rust fungi are a species-rich and important group of plant pathogens worldwide. This study has shown that rust fungi evolved in a much shorter time period than was previously estimated. Host jumps explain how rust fungi have become widespread pathogens on a wide variety of plants in $<160 \mathrm{Ma}$. There are various practical implications. For example, narrow host specificity is a tacit requirement, if not assumption, for the use of rust fungi as biological control agents. In light of evidence showing that rust fungi have diversified by frequent host jumps, biological control programs may need to apply greater amounts of caution before rusts are introduced into naïve ecosystems.

\section{Acknowledgements}

We thank the members of the Tree Protection Co-operative Programme (TPCP), the THRIP initiative of the Department of Trade and Industry, and the Department of Science and Technology (DST)/National Research Foundation (NRF) Centre of Excellence in Tree Health Biotechnology (CTHB) for financial assistance that made this study possible. This work was partly funded by the Australian Biological Resources Study, grant number RFL212-33. The authors also thank anonymous reviewers whose suggestions helped to improve the submitted manuscript.

\section{Author contributions}

A.R.M. and M.J.W. planned and designed the research. A.R.M., M.A.vdN. and R.G.S. performed experiments, and analysed data. 
A.R.M., R.G.S., M.A.vdN., J.R., B.D.W. and M.J.W. wrote the manuscript.

\section{References}

Aime MC. 2006. Toward resolving family-level relationships in rust fungi (Uredinales). Mycoscience 47: 112-122.

Aime MC, Matheny PB, Henk DA, Frieders EM, Nilsson RH, Piepenbring M, McLaughlin DJ, Szabo LJ, Begerow D, Sampaio JP et al. 2006. An overview of the higher level classification of Pucciniomycotina based on combined analyses of nuclear large and small subunit rDNA sequences. Mycologia 98: 896-905.

Anikster Y, Wahl I. 1979. Coevolution of the rust fungi on Gramineae and Liliaceae and their hosts. Annual Review of Phytopathology 17: 367-403.

Baum BR, Savile DBO. 1985. Rusts (Uredinales) of Triticeae: evolution and extent of coevolution, a cladistic analysis. Botanical Journal of the Linnean Society 91: 367-394.

Beenken L. 2014. Pucciniales on Annona (Annonaceae) with special focus on the genus Phakopsora. Mycological Progress 13: 791-809.

Beenken L, Zoller S, Berndt R. 2012. Rust fungi on Annonaceae II: the genus Dasyspora Berk. \& M.A. Curtis. Mycologia 104: 659-681.

Berbee ML, Taylor JW. 2010. Dating the molecular clock in fungi - how close are we? Fungal Biology Reviews 24: 1-16.

Bouckaert R, Heled J, Kühnert D, Vaughan T, Wu C-H, Xie D, Suchard MA, Rambaut A, Drummond AJ. 2014. BEAST 2: a software platform for Bayesian evolutionary analysis. PLoS Computational Biology 10: e1003537.

Crane PE, Peterson RS. 2007. Mikronegeria fuchsiae sp. nov., a rust fungus on Fuchsia and Phyllocladus in New Zealand. New Zealand Journal of Botany 45: 707-713.

Cummins GB, Hiratsuka Y. 1983. Illustrated genera of rust fungi, $2^{\text {nd }}$ edn. St. Paul, MN, USA: American Phytopathological Society.

Cummins GB, Hiratsuka Y. 2003. Illustrated genera of rust fungi, $3^{\text {rd }}$ edn. St Paul, MN, USA: American Phytopathological Society.

Cunningham GH. 1931. The rust fungi of New Zealand: together with the biology, cytology and therapeutics of the Uredinales. Dunedin, New Zealand: John McIndoe.

Doungsa-ard C, McTaggart AR, Geering ADW, Dalisay TU, Ray J, Shivas RG. 2015. Uromycladium falcatarium sp. nov., the cause of gall rust on Paraserianthes falcataria in south-east Asia. Australasian Plant Pathology 44: 25-30.

Drummond AJ, Bouckaert RR. 2015. Bayesian evolutionary analysis with BEAST. Cambridge, UK: Cambridge University Press.

Drummond AJ, Suchard MA, Xie D, Rambaut A. 2012. Bayesian phylogenetics with BEAUti and the BEAST 1.7. Molecular Biology and Evolution 29: 19691973.

Hart JA. 1988. Rust fungi and host plant coevolution: do primitive hosts harbor primitive parasites? Cladistics 4: 339-366.

Hedges SB, Marin J, Suleski M, Paymer M, Kumar S. 2015. Tree of life reveals clock-like speciation and diversification. Molecular Biology and Evolution 32: 835-845.

Henk DA, Vilgalys R. 2007. Molecular phylogeny suggests a single origin of insect symbiosis in the Pucciniomycetes with support for some relationships within the genus Septobasidium. American Journal of Botany 94: 15151526.

Hennen JF, Buriticá P. 1980. A brief summary of modern rust taxonomic and evolutionary theory. Reports of the Tottori Mycological Institute 18: 243-256.

Ho SYM. 2007. Calibrating molecular estimates of substitution rates and divergence times in birds. Journal of Avian Biology 38: 409-414.

Katoh K, Asimenos G, Toh H. 2009. Multiple alignment of DNA sequences with MAFFT. In: Posada D, ed. Bioinformatics for DNA sequence analysis. New York, NY, USA: Humana Press, 39-64.

Kinloch BB. 2003. White pine blister rust in north america: past and prognosis. Phytopathology 93: 1044-1047.

Leppik EE. 1953. Some viewpoints on the phylogeny of rust fungi I. Coniferous rusts. Mycologia 45: 46-74.
Leppik EE. 1965. Some viewpoints on the phylogeny of rust fungi. V. Evolution of biological specialization. Mycologia 57: 6-22.

Liberato JR, McTaggart AR, Shivas RG. 2014. First report of Masseëlla capparis in Australia. Australasian Plant Disease Notes 9: 121.

Liu K, Warnow TJ, Holder MT, Nelesen SM, Yu J, Stamatakis AP, Linder CR. 2012. SATe-II: very fast and accurate simultaneous estimation of multiple sequence alignments and phylogenetic trees. Systematic Biology 61: $90-106$.

Lutz M, Bauer R, Begerow D, Oberwinkler F. 2004. TuberculinaThanatophytum/Rhizoctonia crocorum-Helicobasidium: a unique mycoparasiticphytoparasitic life strategy. Mycological Research 108: 227-238.

Magallón S, Hilu KW, Quandt D. 2013. Land plant evolutionary timeline: gene effects are secondary to fossil constraints in relaxed clock estimation of age and substitution rates. American Journal of Botany 100: 556-573.

Maier W, McTaggart AR, Roux J, Wingfield MJ. 2015. Phakopsora myrtacearum sp. nov., a newly described rust (Pucciniales) on eucalypts in eastern and southern Africa. Plant Pathology. doi: 10.1111/ppa.12406

Mao K, Milne RI, Zhang L, Peng Y, Liu J, Thomas P, Mill RR, Renner S. 2012. Distribution of living Cupressaceae reflects the breakup of Pangea. Proceedings of the National Academy of Sciences, USA 109: 77937798.

McTaggart AR, Doungsa-ard C, Geering ADW, Aime MC, Shivas RG. 2015. A co-evolutionary relationship exists between Endoraecium (Pucciniales) and its Acacia hosts in Australia. Persoonia 35: 50-62.

McTaggart AR, Geering ADW, Shivas RG. 2013. Thekopsora minima causes blueberry rust in south-eastern Queensland and northern New South Wales. Australasian Plant Disease Notes 8: 81-83.

McTaggart AR, Geering ADW, Shivas RG. 2014. The rusts on Goodeniaceae and Stylidiaceae. Mycological Progress 13: 1017-1025.

van der Merwe MM, Walker J, Ericson L, Burdon JJ. 2008. Coevolution with higher taxonomic host groups within the Puccinial Uromyces rust lineage obscured by host jumps. Mycological Research 112: 1387-1408.

Miller JT, Murphy DJ, Ho SYW, Cantrill DJ, Seigler D. 2013. Comparative dating of Acacia: combining fossils and multiple phylogenies to infer ages of clades with poor fossil records. Australian Journal of Botany 61: 436-445.

Nylander JAA, Wilgenbusch JC, Warren DL, Swofford DL. 2008. AWTY (are we there yet?): a system for graphical exploration of MCMC convergence in Bayesian phylogenetics. Bioinformatics 24: 581-583.

Pegg GS, Giblin FR, McTaggart AR, Guymer GP, Taylor H, Ireland KB, Shivas RG, Perry S. 2014. Puccinia psidii in Queensland, Australia: disease symptoms, distribution and impact. Plant Pathology 63: 1005-1021.

Peterson RS. 1974. Rust fungi with Caeoma-like sori on conifers. Mycologia 66: 242-255.

Rambaut A, Suchard MA, Xie D, Drummond AJ 2014. Tracer v1.6. [WWW document] URL http://beast.bio.ed.ac.uk/Tracer. [accessed 17 July 2015].

Ronquist F, Huelsenbeck JP. 2003. MrBayes 3: Bayesian phylogenetic inference under mixed models. Bioinformatics 19: 1572-1574.

Roy BA. 2001. Patterns of association between Crucifers and their flower-mimic pathogens: host jumps are more common than coevolution or cospeciation. Evolution 55: 41-53.

Sauquet H, Ho SYW, Gandolfo MA, Jordan GJ, Wilf P, Cantrill DJ, Bayly MJ, Bromham L, Brown GK, Carpenter RJ et al. 2012. Testing the impact of calibration on molecular divergence times using a fossil-rich group: the case of Nothofagus (Fagales). Systematic Biology 61: 289-313.

Savile DBO. 1971. Coevolution of the rust fungi and their hosts. The Quarterly Review of Biology 46: 211-218.

Savile DBO. 1976. Evolution of the rust fungi (Uredinales) as reflected by their ecological problems. In: Hecht M, Steere W, Wallace B, eds. Evolutionary biology. New York, NY, USA: Springer, 137-207.

Savile DBO. 1979. Fungi as aids in higher plant classification. Botanical Review 45: 377-503.

Scholler M, Aime MC. 2006. On some rust fungi (Uredinales) collected in an Acacia koa-Metrosideros polymorpha woodland, Mauna Loa Road, Big Island, Hawaii. Mycoscience 47: 159-165. 
Scholler M, Lutz M, Wood A, Hagedorn G, Mennicken M. 2011. Taxonomy and phylogeny of Puccinia lagenophorae: a study using rDNA sequence data, morphological and host range features. Mycological Progress 10: 175-187.

Shivas RG, Beasley DR, McTaggart AR. 2014. Online identification guides for Australian smut fungi (Ustilaginomycotina) and rust fungi (Pucciniales). IMA Fungus 5: 195-202.

Sjamsuridzal W, Nishida H, Ogawa H, Kakishima M, Sugiyama J. 1999. Phylogenetic positions of rust fungi parasitic on ferns: evidence from $18 \mathrm{~S}$ rDNA sequence analysis. Mycoscience 40: 21-27.

Stamatakis A. 2014. RAxML Version 8: a tool for phylogenetic analysis and postanalysis of large phylogenies. Bioinformatics 30: 1312-1313.
Tiffney BH, Barghoorn ES. 1974. The fossil record of the fungi. Occasional Papers of the Farlow Herbarium of Cryptogamic Botany 7: 1-42.

Vialle A, Feau N, Allaire M, Didukh M, Martin F, Moncalvo J-M, Hamelin RC. 2009. Evaluation of mitochondrial genes as DNA barcode for Basidiomycota. Molecular Ecology Resources 9: 99-113.

de Vienne DM, Refregier G, Lopez-Villavicencio M, Tellier A, Hood ME, Giraud T. 2013. Cospeciation vs host-shift speciation: methods for testing, evidence from natural associations and relation to coevolution. New Phytologist 198: 347-385.

Wingfield BD, Ericson L, Szaro T, Burdon JJ. 2004. Phylogenetic patterns in the Uredinales. Australasian Plant Pathology 33: 327-335.

\section{About New Phytologist}

- New Phytologist is an electronic (online-only) journal owned by the New Phytologist Trust, a not-for-profit organization dedicated to the promotion of plant science, facilitating projects from symposia to free access for our Tansley reviews.

- Regular papers, Letters, Research reviews, Rapid reports and both Modelling/Theory and Methods papers are encouraged. We are committed to rapid processing, from online submission through to publication 'as ready' via Early View - our average time to decision is $<27$ days. There are no page or colour charges and a PDF version will be provided for each article.

- The journal is available online at Wiley Online Library. Visit www.newphytologist.com to search the articles and register for table of contents email alerts.

- If you have any questions, do get in touch with Central Office (np-centraloffice@lancaster.ac.uk) or, if it is more convenient, our USA Office (np-usaoffice@lancaster.ac.uk)

- For submission instructions, subscription and all the latest information visit www.newphytologist.com 